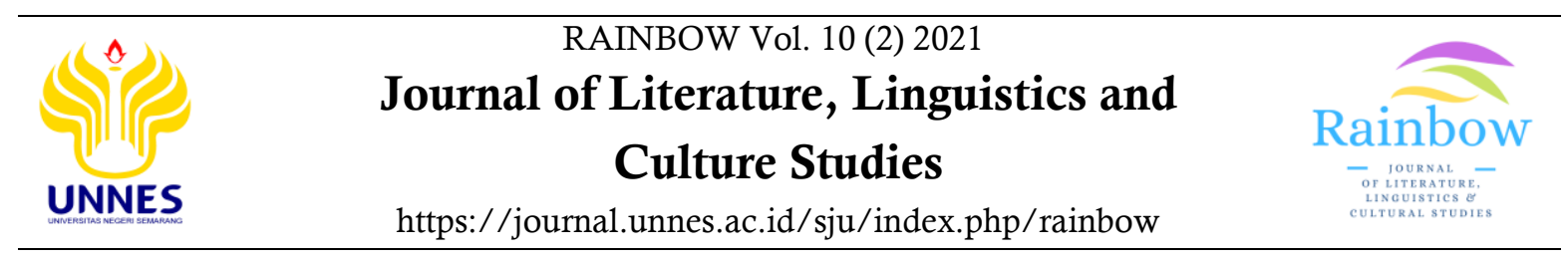

\title{
A day of history and hope: A critical discourse analysis of Joe Biden's Inauguration speech
}

\author{
Teguh Puja Pramadya ${ }^{1 凶}$, Anna Desiyanti Rahmanhadi ${ }^{2}$ \\ ${ }^{1}$ Universitas Widyatama, Indonesia, ${ }^{2}$ Highfield Secondary School, Indonesia
}

\begin{tabular}{|c|c|}
\hline Article Info & Abstract \\
\hline $\begin{array}{l}\text { Article History: } \\
\text { Received } \\
\text { 26 February } 2021 \\
\text { Approved } \\
\text { 04 September } 2021 \\
\text { Published } \\
\text { 30 October } 2021 \\
\text { Keywords: } \\
\text { Critical Discourse } \\
\text { Analysis, inauguration } \\
\text { speech, Joe Biden }\end{array}$ & $\begin{array}{l}\text { This article explores how President-elect Joe Biden used the rhetoric of political language } \\
\text { in his inauguration speech as an attempt to showcase his policy plans as well as his political } \\
\text { views on the American political scene. This article also looks at how each of the political } \\
\text { messages in his inauguration speech shows the ideology and power that Joe Biden believes } \\
\text { in. To provide comprehensive details about the elements of Joe Biden's inauguration } \\
\text { speech, the researchers use Norman Fairclough's idea to view continuing social practice } \\
\text { via the prisms of text, discourse practice, and the sociocultural practice that underpins the } \\
\text { text, or to view the underlying reality that gave rise to the discourse. }\end{array}$ \\
\hline $\begin{array}{l}\text { How to cite (in APA Sty } \\
\text { Pramadya, T. P., \& Ra } \\
\text { Inauguration speech. } \\
\text { https://doi.org/10.1529 }\end{array}$ & $\begin{array}{l}\text { le): } \\
\text { hmanhadi, A. D. (2021). A day of history and hope: A critical discourse analysis of Joe Biden's } \\
\quad \text { Rainbow: Journal of Literature, Linguistics and Culture Studies, 10(2), } 1-10 . \\
\text { trainbow.v10i2.45383 }\end{array}$ \\
\hline
\end{tabular}

\section{INTRODUCTION}

Political speeches delivered during the presidential inauguration ceremony are a significant aspect of a larger political phenomenon. Because political discourse is fundamentally distinct from other forms of political conversation. As a result, political remarks cannot be considered unprompted. Political speeches, like other messages, have purpose and power, as they can expose a person's political objectives and attitude. Language is critical in this process, as language is used to organize, accompany, encourage, and operate all political activities. Inaugural addresses are one of the most powerful tools for influencing public opinion. Thus, by influencing (or strengthening) public opinion, one can influence (or strengthen) the current power structure. The inaugural address also serves a significant role and has a significant impact as political discourse. Specifically, as a method of creating the agenda by

\footnotetext{
Corresponding author:

E-mail: teguhpuia@gmail.com
}

providing information about future goals and connected actions to previous actions (Graber, 1981, p. 196) in Cheng (2006).

Political discourse is often conveyed to a large audience, thus, its influence is enormous. In the same way, Joe Biden's inaugural speech has a huge potential to influence the Americans to act and take part in the democratic constellation of the United States today. Language plays a critical role in politics because, in addition to serving as a means of communication, it can help shape the speaker's image in the eyes of the public who receives the message (Manan, 2019, p. 55). In this regard, Chen (2018) in Jegede (2020) also said that the impact of political speeches, especially the American president, has a very large influence on domestic and international political policies.

A speech that incorporates a variety of influences on public assumptions is a form of discourse practice that may be further investigated 
using a Critical Discourse Analysis theory (afterward CDA). However, in order to comprehend the CDA more properly, one must first understand what discourse is. Discourse is a collection of messages, both spoken and written, used as a means of communication in which the addressor conveys a concept to the addressee based on a particular context within a community (Foucalt via Jansen, 2008, p. 110). Ayeomono (2001) in Jegede (2020, p. 318) notes that inauguration speech is important in terms of delivering the president-elect a way to talk about his policy. The inauguration speech is the president-elect's first official opportunity to reaffirm what has been said in the previous campaign. Additionally, this can be utilized as a platform to communicate any government policy plans (Manzano \& Orquijo, 2020, p. 84).

Discourse Analysis (DA) is frequently used to refer to research or analysis that focuses on internal language features. Meanwhile, Critical Discourse Analysis (CDA) is described as an attempt to interpret a text on a social occurrence in order to ascertain its underlying interests. CDA can be used to investigate discourse as a social practical form in order to ascertain the relationship between discourse and sociocultural development in various social domains on a linguistic level (Eriyanto, 2006, p. 7). As such, it is used to evaluate transdisciplinary discourse in areas such as politics, racism, gender, hegemony, culture, and social class.

This article presents the exploration of the speech delivered by the newly elected president of the United States, Joe Biden, in the light of CDA. It is therefore used as an analytical approach to see how Biden's chosen language is used when viewed in its construction and in the social context that surrounds it. Fairclough (2001) believes that the choice of words and syntax patterns in the discourse of a language has a very strong influence. Therefore, "every discourse practice, every social and political point of view can be clearly seen and cannot be covered up again" (Sipra \& Rashid, 2013, p. 28).

Several previous studies have explored the speech of public figures such as Barack Obama
(Kazemian \& Hashemi, 2014), John May (Prescilla \& Amalia, 2018), Leonardo DiCaprio (Prihandini \& Putra, 2019), Jokowi (Manan, 2019), Nadhiem Makarim (Magfiroh \& Triyono, 2020) using CDA as the analytical approach. In the study by Kazemian and Hashemi (2014) for instance, Barack Obama's speech in 2012 is analyzed using the CDA in the viewpoint of Systemic Functional Linguistics and Rhetoric. The study finds out that some linguistic elements such as nominalization, parallelism, unification strategies, and modality have dominated Obama's speeches. It also relies heavily on rhetorical devices which aim to persuade, inform, convey personal ideologies, emphasize inter-relatedness of delivered messages, signify differentiation, and demonstrate the orator's solidarity with the audience.

Fairclough (1992), in Discourse and Social Change, explains that the character of discourse analysis lies in its textual orientation. This means that the theory of CDA is closely related to an analysis of discourse within texts, both written and/or spoken. The main focus of CDA is any kind of speech provided publicly e.g advertisement, political propaganda, laws, and regulations, news reports, etc. on which the relationships among language, ideology, and power can be explored.

Biden's inaugural speech is analyzed prominently by applying Norman Fairclough's principle of a 3D model. This article explores how President-elect Joe Biden used the rhetoric of political language in his inauguration speech as an attempt to showcase his policy plans as well as his political views on the American political scene. This article also looks at how each of the political messages in his inauguration speech shows the ideology and power that Joe Biden believes in. The speech is then viewed to evoke different emotions as well as to motivate the Americans to rise and face the crisis and challenges across the United States today.

\section{METHODS}

This study examines Joe Biden's inaugural speech to see how power and ideology play out in 
his political speech. Researchers are concerned about Biden's use of expressions and some of the textual elements in the phrases. The most important aspect of this study is how the speech will engage and persuade the audience of Biden's vision and ambitions for America. This study's methodology is a critical discourse analysis based on Norman Fairclough's point of view.

This study focused on Joe Biden's inauguration address as the 46th President of the United States on January 20, 2021. The inauguration took place on the Western Front of the US Capitol in Washington, D.C. This study's data is based on Joe Biden's speech transcription. This article contains an italicized speech by Taylor (2021). Transcripts are used to help researchers evaluate data and guarantee that data is accurate and accounted for.

\section{RESULTS AND DISCUSSION}

Fairclough (2001) writes in his book Language and Power that language is rooted in society as a social practice inside the framework of linguistic phenomena as social phenomena and vice versa. CDA makes an attempt with this characteristic to reveal the concealed interpretation of an ideology embedded in a particular discourse. It reveals the ideological presumption in order to show the text's exercise of authority.

As a theory, CDA tries to investigate the language use of power holders that makes it the central concept. He proposed a theory of three dimensions (3D) of communicative events namely social dimension, discursive dimension, and a textual dimension (Jorgensen et al, 2002, p. 69). These dimensions are intertwined, it is not enough to analyze only a text; to obtain a comprehensive analysis to analyze 'the relationship between text, interactions, and context' is essential (Fairclough, 2001, p. 21)

This section summarizes the findings of the research, which incorporated Norman Fairclough's three-dimensional critical discourse analysis. The findings are presented in the form of descriptions and discussed in detail.

\section{Dimension of Text}

The researchers identified numerous themes and also the identification procedure employed in Joe Biden's inaugural speech using various language strategies.

\section{The use of "Identification"}

The "identification" approach, one of the rhetorical styles, plays an enormous role in the inaugural speech. Because by using this identification rhetoric, Joe Biden can strengthen his identity with the identity of his audience. So there is an emotional closeness between the two. According to Zheng (2000), as cited by Cheng (2006, p. 594), politicians employ the "identification" approach as a targeting method to appeal to specific segments of the community. By applying this inclusive strategy, they can persuade their audience that both they and their ideas are 'of the people' and therefore gain the support of these groups' members.

The inclusive technique of "we" is used repeatedly in many parts of Joe Biden's speech. One of the most repeated pronouns in Joe Biden's inaugural speech is the use of we and $I$ inclusive. From the speech, one can see that we inclusive takes up 109 times in Biden's speech, a big number of a personal pronoun that one can use for a short inaugural speech. We in Biden's speech refers to Biden himself with his administration, together with the audience as his biggest supporters. $\mathrm{He}$ wanted to emphasize that the winning of this presidential election is not only about him and his administrators being the occupants of the Capitol, but also about all American civilians who have voted for him and who have not, will get benefit in terms of opportunity security, liberty, dignity, respect, and honor. This, of course, indicates an attempt of Biden to invite the whole crowd to come with him to sort out all the work he has to conduct. Thus, to unite, to do what is right for the good of all, and to minimize personal selfishness. Take for example,

We can right wrongs. We can put people to work in good jobs. We can teach our children in safe schools. We can overcome the deadly virus. We can reward work and rebuild the middle 
class and make healthcare secure for all. We can deliver racial justice and we can make America once again, the leading force for good in the world.

On the other side, $I$ has appeared not so much, only 36 times in the speech. Generally, $I$ seldom comes out in inaugural addresses because it relatively seems to be too exclusive. Inaugural speech is seen as the moment for the people as its political goal. However, when it is important for the speaker to show his position and power, the personal pronoun of $I$ can find its place as shown below,

And I pledge this to you, I will be a president for all Americans. I promise you, I will fight as hard for those who did not support me, as for those who did.

Before God and all of you, I give you my word. I will always level with you. I will defend the Constitution. I'll defend our democracy. I'll defend America and will give all, all of you keep everything I do in your service.

Further, from the excerpt above it can be seen that the personal pronoun $I$ is deployed in the speech only when Biden use of certain verbs such as "guarantee", "pledge" and "promise", which shows his optimism and a high degree of certainty in his power and ability for the betterment and prosperity of America. As mentioned earlier, the use of certain verbs such as "guarantee", "pledge" and "promise" that appear repeatedly in his speech as shown by the excerpt below:

If we do that, I guarantee you, we will not fail. We have never, ever, ever, ever failed in America when we've acted together. And so today, at this time in this place, let's start afresh all of us.

Yet hear me clearly, disagreement must not lead to disunion. And I pledge this to you, I will be a president for all Americans, all Americans. And I promise you, I will fight as hard for those who did not support me, as for those who did.

Thinking about their families, about what comes next. I promise you I get it.

And I promise you this, as the Bible says,
"Weeping may endure for a night, but joy cometh in the morning." We will get through this together, together.

And this is certain, I promise you, we will be judged you and I, by how we resolve these cascading crises of our era.

These findings show how Biden tries to influence the audience for a specific purpose. Further, it is seen as indication of how much Biden tries to convey his certainty to the audience to do whatever it takes to return America to its former state. Biden also wants to continue to convince his audience that he has a very serious commitment to making it happen.

\section{The use of "metaphor"}

Beer and De Landtsheer (2004, p. 7), as cited in Bataineh (2019), emphasize the significance of how metaphor interacts with international relations. They emphasize the importance of language, particularly metaphorical language, in international politics. Biden used a variety of metaphors to reinforce certain themes that were at the heart of his inaugural address. Such as the use of "a crucible for the ages" to discuss the threats and problems faced by America.

This is America's day. This is democracy's day. $A$ day of history and hope. Of renewal and resolve. Through a crucible for the ages, America has been tested anew and America has risen to the challenge.

Biden said early in his inauguration speech that America was facing a "crucible" moment, a tough test. This can be understood by looking at the socio-political context which is still a very relevant issue and is still the concern of America and even the world, namely the Covid-19 pandemic and poor economic conditions.

Few people in our nation's history have been more challenged or found a time more challenging or difficult than the time we're in now. Once in a century virus that silently stalks the country, has taken as many lives in one year as America lost in all of World War II. Millions of jobs have been lost. Hundreds of thousands of businesses closed. 
This, of course, originally led the sociopolitical dynamics and climate in the American presidential election to encounter numerous issues, since the degree of public confidence in the government is still in a poor state, largely due to measures under the previous administration to deal with the Corona pandemic. In America, the pandemic also carries with it major economic challenges. Unemployment is everywhere and industry losses are taking place all over America (Deutsche Welle (www.dw.com. (2020).

\section{The use of "repetition"}

According to Holmes and Stube (1983, p. 203), as referenced in Bataineh (2019, p. 43), repetition is vital in developing coherence and interpersonal engagement. The inclusion of the phrases such as "democracy" and "unity" throughout Biden's speech emphasizes the significance that Biden is planning and preparing his political agenda for this to occur during his presidency. The phrases "democracy" and "unity" are used so that Biden's audience, particularly the American public, might feel that the polarization that happened during the campaign and election process will cease soon and can be addressed collectively.

Yet hear me clearly, disagreement must not lead to disunion. And I pledge this to you, I will be a president for all Americans, all Americans. And I promise you, I will fight as hard for those who did not support me, as for those who did.

The use of certain vocabulary words, such as "democracy" and "unity", became Biden's repeated words multiple times during his inauguration speech. There are 11 repetitions of Democracy. Meanwhile, there are 9 repetitions for the word unity. These two words become the main essence of Biden's speech. Biden's attitude towards several issues currently being faced by American society also emerged from the vocabulary he chose throughout his speech. This vocabulary is chosen in order to indicate the difficulty level of the problem and Biden's level of confidence in trying to solve it.
Seeing what happened before the inauguration, the attack on the Capitol, and also the political polarization that was getting stronger before and after the election took place became a concern that was also conveyed by Biden. Biden reminds the American society not to be continually divided and end up attacking and blaming one another. Biden reminds the audience that the transfer of power from one period to another always ends well and that must also be done. There can be no violence. Biden cautions that disunion/ polarization in the society is not a solution and is not the path that American society should take. America belongs to everyone. And America can only be successful if everyone sticks together and helps one another.

....But the American story depends not on any one of us, not on some of us, but all of us. On we the people who seek a more perfect union. This is a great nation. We are good people. We'll press forward with speed and urgency for we have much to do in this winter of peril and significant possibilities. Much to repair, much to restore, much to heal, much to build, and much to gain.

In his speech, Biden reminds everyone that there are problems that they need to address, such as the growing and divisive public polarization and problems that arose during the previous electoral process. For instance, the storming of the United States Capitol a few weeks before Biden's inauguration was a riot and brutal assault on the 117th Congress of the United States. In the history of the American presidential race, it is one of the most humiliating occurrences (By The Visual Journalism Team, 2021) (The storming of the US Capitol, 2021).

So now on this hallowed ground where just a few days ago violence sought to shake the capital's very foundation. We come together as one nation, under God, indivisible, to carry out the peaceful transfer of power as we have for more than two centuries.

This riot arose to block the decision to formalize Biden's win concerning the Electoral College vote. These activities emerged out of dissatisfaction with the supporters of Trump and 
out of their skepticism of the outcome of the election. Biden condemns these incidents as a "winter of peril" and wishes that in "perfect union" the American people will revert to their original circumstances.

Biden has sought to warn the public on numerous occasions the bigotry that has arisen in recent years has created prolonged issues. Of necessity, this makes America much farther away from the democratic ideals that it has maintained so long. Biden wanted to note that the only thing that is being fought over again must be the dignity of the country and state.

\section{The use of "antithesis"}

Harris (2005), as cited by Cheng (2006, p. 603), describes the art of persuasion utilizing the antithesis technique, noting that the utilization of distinctions or differences by contrasting two concepts can establish a clear relationship between them and generate a substantial effect. Throughout his address, Joe Biden emphasized the contrasts between these terms and phrases, such as: ... we shall write an American "story of hope, not fear"; "Of unity, not division". "Of light, not darkness". We've learned again that "democracy is precious. Democracy is fragile".

The language techniques used throughout Biden's speech place a strong emphasis on agendasetting, as well as on power and Biden's views on the issues confronting America.

\section{Dimension of Discursive Practices}

In Eriyanto (2001, p. 286-288), Fairclough asserts that discursive practice is a facet of the process of text production and consumption. The text production process is more oriented towards the text's author. This process is connected to personal experience, understanding of one's habits, social surroundings, conditions, circumstances, and context, among other things, that are relevant to the self or author of the work. Meanwhile, text consumption varies according to the reader's or viewer's experience, knowledge, and social situation.

According to Fairclough's (2010) discourse perspective on 'text production,' the results suggested that Biden's address integrated a variety of genres and discourses (i.e., religious, constitutional). This is evident in the positioning of the concept of American Exceptionalism, as well as the spiritual/religious approach demonstrated by Biden's usage of Bible texts to frame his future and current perspectives. The inclusion of this holy verse does not immediately transform this inaugural address into a religious phenomenon; rather, it remains a political phenomenon for a president who places importance on religious principles.

In terms of 'text distribution,' Biden constructed his message through the use of previously published texts and genres. According to Fairclough (2010), intertextuality is the process through which texts are modified from the past to the present. By making the connection to George Washington, Abraham Lincoln, and Dr. Martin Luther King, Jr., Biden's inaugural address gained greater patriotic symbolism.

\section{Dimension of Social Practices}

Considering that the inaugural address is a form of political discourse, it is certain that it has its own conventions and characteristics as a genre. According to Hart and Sparrow (2001), as cited in Mirzaei et al. (2016), the majority of inaugural addresses are intended to communicate the nation's "civil, religious, and idealized identity." Additionally, Mirzaei et al. (2016, p. 40) highlight that each speaker is supposed to unite the audience and convey the shared ideals and objectives that the new office bearers would uphold.

Biden began his inauguration address by addressing numerous individuals, including Chief Justice Roberts, Vice President Harris, Speaker Pelosi, Leader Schumer, Leader McConnell, and Vice President Pence, before continuing with "my distinguished guests, my fellow Americans." One can see from this salutation the audience that Biden addressed, not only those who attended his inaugural address, but also a broader audience, namely Americans. Biden also implied at the start of his inauguration speech that the previous election results that led him to the presidency were 
part of the people's will and a type of democratic victory.

Today we celebrate the triumph, not of a candidate, but of a cause, the cause of democracy. The people, the will of the people, has been heard and the will of the people has been heeded.

Biden has also sought on several times to repromote the fundamentals of America's national philosophy, which is frequently the foundation for numerous policies and pledges made by American presidents, especially American Exceptionalism. American Exceptionalism is an ideology, or a concept of manifest destiny, in which Americans think that America's principles, government structure, and history are unique and worthy of universal praise. They also imply that the United States is destined and entitled to play a special and beneficial role on the international stage (Walt, 2011).

This is a great nation. We are good people. And over the centuries through storm and strife, in peace and in war, we've come so far, ...

We can deliver racial justice and we can make America once again, the leading force for good in the world.

So, here's my message to those beyond our borders, ... we'll lead not merely by the example of our power, but by the power of our example. It will be a strong and trusted partner for peace, progress, and security.

That America secured liberty at home and stood once again as a beacon to the world. That is what we owe our forebearers, one another and generation to follow.

The expressions "a great nation," "leading force for good in the world," "a strong and trusted partner," and "beacon to the world" all highlight how philosophy, and particularly Biden's policy ideas, will be carried out during his administration. Biden does not limit his use of these terms to the domestic or in-group context, but also to the world, especially "to those beyond our borders".

Joe Biden's opinions and principles as a representation of the Democratic Party were also represented in various sections of his inaugural address. This is evident in Biden's attitude, which reflects the policies in which the Democratic party strongly believes, such as the attitude in foreign policy, Democrats generally advocate internationalism and multilateralism - that is, the conduct of foreign affairs through international institutions such as the United Nations-to isolationism and unilateralism. And other populist social measures; government funded social services and benefits for the poor, the unemployed, the elderly, and other groups; and preservation of civil rights (Democratic Party | History, Definition, \& Beliefs 2021).

Biden implies that the Trump administration's cold and distant attitude toward allies is over, that the United States' reputation has reached rock bottom, and that America can once again be trusted to uphold its commitments. Biden is expected to reintroduce himself to the Paris climate deal and the World Health Organization, both of which Trump withdrew from (Weintraub, 2021) (Biden Moves To Have U.S. Rejoin Climate Accord, 2021). This is consistent with the Democratic Party's political and ideological perspectives, which are more likely to support America to foster broad and robust international cooperation.

We will repair our alliances and engage with the world once again, not to meet yesterday's challenges, but today's and tomorrow's challenges.

Certain Democratic principles, both explicitly and implicitly, are reflected and articulated clearly in Biden's address. Biden's inauguration speech's utilization of themes and critical topics created a significant contrast between himself and the previous government, specifically Donald Trump, the Republican party's representative president. Naturally, this is understandable, as Biden's inauguration address does not stand alone or in a vacuum. Numerous passages in Biden's address reflected the Democratic party's fundamental ideals and values.

Allusions to numerous significant individuals in American history also add an 
element of intertextuality to Biden's inauguration speech, enhancing its importance. The reference to George Washington as America's first president and Abraham Lincoln as the signer of the Emancipation Proclamation appears to reinforce the idea that all of America's values and the struggle to overcome all of the problems encountered thus far are long-held ideals that must be preserved. Biden also quoted a Bible scripture, mentioned a "church" which is a worship place, and referred to Saint Augustine; these demonstrate that Biden purposefully used religion in his inauguration speech to connect with his audience and express that Biden is a person who upholds religious principles.

Many centuries ago, Saint Augustine, a Saint in my church wrote that a people was a multitude defined by the common objects of their love, defined by the common objects of their love.

I promise you this, as the Bible says, "Weeping may endure for a night, but joy cometh in the morning." We will get through this together, together.

Additionally, Biden asks his audience to put aside their differences and engage in political reconciliation, so that the past polarization and disunion can be remedied collaboratively. Additionally, Biden described the pre-inauguration "riot" as an endeavor that was harmful to politics and the democratic system.

And here we stand just days after a riotous mob thought they could use violence to silence the will of the people, to stop the work of our democracy, to drive us from this sacred ground.

Nonetheless, Biden used the occasion to highlight that he is president for all Americans, both those who voted for him and those who previously opposed him and did not contribute to his election. Biden made it clear that dissent is a central aspect of democracy, and that whatever transpired during the previous election was a part of the democratic process that must be respected. As a result, Biden pledged to continue fulfilling his constitutional obligations as president to all Americans.
To all those who did not support us, let me say this. Hear me out as we move forward. Take a measure of me and my heart. If you still disagree, so be it. That's democracy. That's America, the right to dissent peaceably within the guard rails of our Republic

And I pledge this to you, I will be a president for all Americans, all Americans. And I promise you, I will fight as hard for those who did not support me, as for those who did.

In many of his part of inaugural address, Biden promised to solve America's issues. These issues include handling the virus, employment losses, business closures, and racial inequality. Biden also mentioned Joe Biden's father and the approach Biden hopes to use to address these economic and health issues. This echoes Biden's emphasis on American society's struggles, which his first and closest family shares.

Look, I understand that many of my fellow Americans view the future with fear and trepidation. I understand they worry about their jobs. I understand like my dad, they lay in bed at night, staring at the ceiling wondering, "Can I keep my healthcare? Can I pay my mortgage?" Thinking about their families, about what comes next.

Biden has also emphasized the importance of confronting issues such as distrust and racial injustice with a call to reunite and overcome the "uncivil war" that has overtaken most of the American society. "We must end this uncivil war that pits red against blue, rural versus urban, conservative versus liberal."

\section{CONCLUSION}

Throughout the speech, personal pronouns and speech acts corroborate the meaning of this political discourse. The fact that "we" outnumber "I" in the study of personal pronouns demonstrates Biden's familiarity with his audience and the smallest speaker-audience distance possible. Joe Biden used a variety of methods and language tactics to communicate critical information about his policies and opinions to his primary audience at the time, the American people. The use of 
"identification," "repetition," and persuasive techniques, among others, serves as a powerful reminder to Americans of the principles and notions of American Exceptionalism that have been reiterated by numerous former American presidents. Additionally, Joe Biden intends to strengthen and encourage an optimistic attitude and action in the face of a flurry of health, economic, cultural, and social problems both prior to and during his presidency. The sense of unity and democratic principles are the primary cornerstones of the Joe Biden administration.

\section{REFERENCES}

Biden Moves To Have U.S. Rejoin Climate Accord. (2021, January 20). NPR.org. https://www.npr.org/sections/inaugurationday-live-

updates/2021/01/20/958923821/biden-movesto-have-u-s-rejoin-climate-accord

Build Back Better: Joe Biden's Jobs and Economic Recovery Plan for Working Families | Joe Biden for President: Official Campaign Website. (2020, August 6). Joe Biden for President: Official Campaign Website. https://joebiden.com/build-back-better/

By The Visual Journalism Team. (2021, January 7). Capitol riots: A visual guide to the storming of Congress. BBC News; BBC News. https://www.bbc.com/news/world-us-canada55575260 .

Cheng, M. (2006). Constructing a new political spectacle: Tactics of Chen Shui-bian's 2000 and 2004 inaugural speeches. Discourse \& Society, 17(5), 583-608. https://doi.org/10.1177/0957926506066297

Deutsche Welle (www.dw.com. (2020). Lima Masalah Utama dalam Pemilu AS । DW |27.10.2020.DW.COM.

https://www.dw.com/id/lima-masalah-utamadalam-pemilu-as/a-55402124.

Eriyanto. (2001). Analisis Wacana. Yogyakarta: LKiS.

Eriyanto. (2006). Analisis Wacana: Pengantar Analisis Teks Media. Yogyakarta: LKiS.

Fairclough, N. (1992). Discourse and social change (Vol. 10). Cambridge: Polity press.

Fairclough, N. (2001). Language and power. Pearson Education.

Fairclough, N. (2010). Critical discourse analysis: The critical study of language. London: Longman
Jansen, I. (2008). Discourse analysis and Foucault's" Archaeology of knowledge". International Journal of Caring Sciences, 1(3), 107.

Jegede, O. O. (2020). Syntactic analysis of Donald Trump's inaugural speech. ELS Journal on Interdisciplinary Studies in Humanities, 3(3), 317327. https://doi.org/10.34050/elsjish.v3i3.11068

Jørgensen, M. W., \& Phillips, L. J. (2002). Discourse analysis as theory and method. Sage.

Kazemian, B., \& Hashemi, S. (2014). Critical discourse analysis of Barack Obama's 2012 speeches: Views from systemic functional linguistics and rhetoric. Theory and Practice in Language Studies (TPLS), $\quad 4(6), \quad 1178-1187$. https://doi.org/10.4304/tpls.4.6.1178-1187

Maghfiroh, A., \& Triyono, S. (2020). The Ideological Embodiment on Nadiem Makarim's Speech: A Critical DiscourseAnalysis. Indonesian Journal of EFL and Linguistics, 5(1), 97-111.

Manan, N., A. (2019). 'Sontoloyo' and 'Genderuwo'; Critical Discourse Analysis on Jokowi's Utterance. Langkawi: Journal of The Association for Arabic and English, 5 (1), 55-66. DOI: http://dx.doi.org/10.31332/1kw.v5i1.1257

Manzano, Japhet E. \& Zachi Einna R. Orquijo. (2020) Political commitments and ideologies: A diachronic transitivity analysis of Philippine presidents' inaugural speeches. Asian Journal of English Language Studies (AJELS), 8, 83-109.

Mirzaeila, Azizullah; Mahmood Hashemian, Fatemeh Safari. (2016). Exploring Rhetorical-Discursive Moves in Hassan Rouhani's Inaugural Speech: A Eulogy for Moderation. International Journal of Society, Culture \& Language, 4(2), 39-54.

Presidential Inaugurations: The Inaugural Address. (2021). WHHA (En-US). https://www.whitehousehistory.org/presidenti al-inaugurations-the-inaugural-address.

Prihandini, A., \& Putra, I. P. (2019). Interpersonal metafunction in Leonardo Dicaprio speech. English Journal Literacy Utama, 3(1), 40-46.

Sipra, M. A., \& Rashid, A. (2013). Critical discourse analysis of Martin Luther King's speech in sociopolitical perspective. Advances in Language and Literary Studies, 4(1), 27-33. https://doi.org/10.7575/aiac.alls.v.4n.1p.27

Tawfiq Bataineh, M. (2019). Linguistic and pragmatic devices in king Abdullah's speech: A political discourse analysis. International Journal of Applied Linguistics and English Literature, 8(2), 40-44. https://doi.org/10.7575/aiac.ijalel.v.8n.2p.40 
Taylor, R. (2021, January 20). Joe Biden First Speech as President: Full Transcript at Inauguration. Rev; Rev.

https://www.rev.com/blog/transcripts/joebiden-first-speech-as-president-full-transcript-atinauguration,

The storming of the US Capitol. (2021). BBC News. https://www.bbc.com/news/av/world-uscanada-55641714

Walt, S. M. (2011, October 11). The Myth of American Exceptionalism. Foreign Policy; Foreign Policy. https://foreignpolicy.com/2011/10/11/themyth-of-american-exceptionalism/
Weintraub, K. (2021, January 22). Biden administration renewed support for World Health Organization is "good news for America and the world," scientists say. USA TODAY; USA TODAY. https://www.usatoday.com/story/news/health /2021/01/22/scientists-applaud-biden-decisionrejoin-world-health-organization/4243377001/

Prescilla, Yesvika Fibry \& Resti Amalia. (2018). A Critical Discourse Analysis and Illocutionary Acts of John May's Speech In The Duke Of Edinburgh's Ceremony Award. Getsempena English Education Journal, 5(2), 126-133. 